\title{
Self-Construction in The Importance of Being Earnest from the Perspective of Lacan's Mirror Stage Theory
}

\author{
Lulu Wang \\ East China University of Science and Technology, Shanghai, China \\ Email: tscxd@foxmail.com
}

How to cite this paper: Wang, L.L. (2020) Self-Construction in The Importance of Being Earnest from the Perspective of Lacan's Mirror Stage Theory. Open Access Library Journal, 7: e6475.

https://doi.org/10.4236/oalib.1106475

Received: May 27, 2020

Accepted: June 21, 2020

Published: June 24, 2020

Copyright $\odot 2020$ by author(s) and Open Access Library Inc.

This work is licensed under the Creative Commons Attribution International License (CC BY 4.0).

http://creativecommons.org/licenses/by/4.0/

\section{(c) (i) Open Access}

\begin{abstract}
The Importance of Being Earnest is the most representative play of Wilde. Since the publication of it, domestic and foreign scholars have demonstrated it from many perspectives. This paper employs Lacan's mirror stage theory to analyze the self-construction process of "identification-disintegration-reidentfication" of Jack and Algernon, the two protagonists in the play, that is, to identify themselves with the mirror images, discover the misidentification of themselves, get rid of the mirror images and reidentify themselves. It is emphasized that the self-construction process of Jack and Algernon is based on the influence of the other.
\end{abstract}

\section{Subject Areas}

Literature

\section{Keywords}

The Importance of Being Earnest, Oscar Wilde, Mirror Stage Theory, The Other

\section{Introduction}

The Importance of Being Earnest, the last play of Oscar Wilde, is one of his greatest comedies. Jack, one of the heroes in the play, pretended to be Ernest, who is a fictional character made up by him, to make it easier for him to travel between London and the countryside. Algernon, similarly, invented a friend called Bunbury, who is always ill in bed and needs his care, to avoid certain occasions that he doesn't want to attend. They won the love of Cecily and Gwendolen respectively with the fictitious identity of "Ernest", but their lies were soon 
debunked. Eventually, they clarified the misunderstandings with the help of others and their real identities were recognized.

Researches have been done from many perspectives by domestic and foreign scholars since the publication of the play. Figures of speech applied by Wilde in the characters' discourse, such as satire, irony, paradox, pun, have been studied at length. Otto Reinert (1956) [1] explains the satiric strategy as well as the successful integration of tone and plot in the play, showing that it is not only good fun but also a great play. L.A. Poague (1973) [2], in order to elucidate Wilde's writing style, puts forward five types of irony in the play, including truth, reversal, comparison, situation and the literal mind. Studies are also abundant in character and structural analysis, Wilde's aesthetic beliefs and moral values displayed in the play.

In addition, psychological studies related to people's personalty and identity are also done. As Christopher Craft (1990) [3] maintains, it can be concluded from the play that what Wilde seeks is "the vertigo of substitution and repetition" rather than "the earnest disclosure of a single and singular identity". Sarah Balkin (2016) [4] believes that the play puts the personality into a living human body with Wilde's unification of the characters' desire under one name.

In the process of character analysis, it is found that the self-construction of Jack and Algernon is realized with the help of others, which is in line with Jacques Lacan's view on people's self-identification process in Mirror Stage Theory. However, it does not raise much attention from the critics. This paper elaborates on others' functions in Jack's and Algernon's self-construction process from the perspective of Lacan's Mirror Stage Theory.

\section{Lacan's Mirror Stage Theory}

Jacques Lacan's Mirror Stage Theory involves a wide range of topics and itcan be summed up in the following two aspects: demonstrating the process of people's self-recognition in mirror stage and discussing the influence of mirror imagesonpeople in the process.

In Mirror Stage, an infant of 6 to 18 months sees his image in the mirror and recognizes himself for the first time, discovering that his body is a complete unity and he is in control of it. He goes through three stages in mirror stage: at first, the infant is not able to tell the difference between other people and himself, mistaking his mirror image for a playmate existing in the real world. In the second period, he discovers that the mirror image is only a reflection of others, which does not have physical form in the real world. With the development of his physical organs and the confirmation from others, such as his parents, he finally identifies himself with his own mirror image and gains a sense of uniformity and consistency. From then on, a sense of self-awareness is developed and his ego, an aggregation of ideal images, is gradually formed in his mind. His identification with the mirror image, however, is mis-recognition in essence due to the imaginary nature of the image. 
According to Lacan, the mirror stage appears repeatedly throughout one's life in a broad sense. He applies the concept of "the other" to refer to objects that exert influence on the subject and contributes to the formation of its ego in mirror stage. A person can only achieve self-realization when his ego, an imaginary self, is formed and then broke with the help of the other. In the play The Importance of Being Earnest, the people around Jack and Algernon and even themselves play the role of the other in their self-construction process.

\section{Self-Construction of Jack and Algernon under the Influence of the Other}

The self-construction process of Jack and Algernon is in accord with that of "identification-disintegration-reidentfication" in Lacan's Mirror Stage Theory. At first, they identified themselves with Ernest and Bunbury, who were imaginary figures invented by them, to gain recognition from others. However, Ernest and Bunbury are merely their mirror images, which is imaginary in essence. Therefore, the recognition and identification of them is delusive. Later, their mis-recognized identities were revealed in the interaction with others. Eventually, they established their real identities due to the other' help.

In the self-construction process, Jack and Algernon are lack of autonomy with their ego determined by external powersrather than themselves. According to Lacan, one exists in the being of others, that is, the subject is constructed on the basis of others. Only when others are recognized by the subject and their influences are integrated into the subject, can it be socially accepted. In different stages of the play, different characters play the role of the other and all of them are critical to the self-construction process of Jack and Algernon.

\subsection{The Falsity of Self-Identification}

Jack, in order to make it easier for him to travel between town and the countryside, invented a brother called Ernest, who is a profligate living in the Albany and always gets into trouble. Every time he wanted to go to town, he made an excuse that he needed to help his brother Ernest to deal with some problems while he pretended to be Ernest as soon as he got there. According to Lacan, self-identification is the transformation that the subject has when it identifies itself with the mirror image (Zeng, 2017) [5]. Jack confessed to Algernon that his name was "Ernest in town and Jack in the country" (Wilde, 1985) [6]. The process that Jack identifies himself with Ernest functions similarly to the infant in mirror stage. The imaginary identity of Ernest serves as a mirror image of Jack, which enables him to achieve his purpose, thus giving him a feeling of mastery and satisfaction. This kind of feeling, however, is of the same nature as the infant's when he stands in front of the mirror moving his limbs and thus gains a sense of controlling over his body. What he sees in the mirror is the ideal image of him rather than the real one. Therefore, the ego he forms on the basis of it is illusive. 
In order to avoid some occasions that he doesn't want to attend, Algernon pretended to have a friend in the name of Bunbury, who is of bad health and needs his care. In many cases, he avoided dining with Aunt Augusta on the excuse of paying a visit to Bunbury who was ill in bed so that he could have time to hang out with his friends. Bunbury is actually his imaginary identity as well the ideal self in the mirror, in the disguise of which he becomes a Bunburyist.

The self-identification of Jack and Algernon, in fact, is illusive because of the imaginary nature of their mirror images. And the recognition of their identities is mis-identification in essence. Their ego was formed by the other due to their initiative to establish a real self with the help of mirror images. His real self does not exist because it has already been alienated by others. "The self of a person is the other in itself and it is placed under the Symbolic order" (Zeng, 2017) [5]. One integrates others into himself and thus is alienated permanently, which reflects the dominant position of the other emphasized by Lacan. The self-consciousness of a person is always at the mercy of others, which are external factors rather than internal ones.

In the play, Algernon once said that "nothing will induce me to part with Bunbury, and if youever get married, which seems to me extremely problematic, you will bevery glad to know Bunbury. A manwho marries without knowing Bunburyhas a very tedious time of it." (Wilde, 1985) [6]. It can be seen from his words that he has already treated Bunbury, his imaginary identity, as an integral part of him. Thereby, he is deprived of autonomy and controlling over himself. His freedom is closely related to Bunbury's health condition: if Bunbury is in good health, his excuse will not work; if Bunbury is badly ill, he can do anything what he wants and avoids unpleasant occasions; however, if unfortunately, Bunbury dies of disease, he will lose his freedom accordingly.

\subsection{The Collapse of Imaginary Identity}

Algernon went to Jack's house in Shropshire, pretending to be Jack's younger brother Ernest. He fell in love with Cecily and got engaged to her secretly. In the meanwhile, Jack, dressed in mourning, returned home and told Miss Prism and Chasuble that Ernest died of a severe chill in Paris. Later on, Gwendolen arrived and met Cecily. During the conversation, they found that they were both engaged to Ernest. Not until the appearance of Jack and Algernon did they clarify misunderstandings and see through Jack and Algernon's tricks.

It is Algernon, Gwendolen and Cecily who lead to the collapse of Jack's imaginary identity. If Algernon did not go to Jack's house in the countryside and was not engaged to Cecily, and Gwendolen and Cecily never met and had a conversation, Jack's lie would not be revealed so soon. Algernon, Gwendolen and Cecily serve as the other in the self-construction process of Jack. Without their confirmation, his real self would not be established. In addition, Jack himself plays the part of the other since he invented Ernest, resulting in the alienation of the subject and thus putting himself in the control of others. 
As soon as she was informed that Gwendolen planned to see Jack in the countryside, Lady Bracknell, Gwendolen's mother and Algernon's aunt, followed her to his house, only to be told that Gwendolen was engaged to Jack and Cecily was engaged to Algernon. She consented to Algernon and Cecily's marriage after knowing that Cecily was in possession of a big fortune. However, Jack revealed Algernon's double identity out of his responsibility for Cecily. Algernon's imaginary identity collapsed thereby. For Algernon, Jack plays the role of the other by helping him get rid of mis-identification. With the help of the other, his self-identification was formed at first but was broken afterwards. To conclude, both Jack and Algernon went through "identification-disintegration" in their self-construction process under the influence of the other.

\subsection{The Reestablishment of Identity}

When Lady Bracknell was about to leave, she met Miss Prism by accident and realized that it was Miss Prism who lost her sister's child twenty-eight years ago. Miss Prism told them where and how she lost the baby and it turned out that Jack was that baby, who is Lady Bracknell's nephew and Algernon's elder brother. Knowing the truth, Jack looked through the Amy Lists and found that his father's Christian name was Ernest. Being the eldest son, he was christened after his father and his name is naturally Ernest. Eventually, Jack and Algernon won Gwendolen's and Cecily's love respectively and the play ended with a happy ending.

Seeing from the whole play, Jack's self-identification process was in the control of the other all along. In the beginning, Gwendolen fell in love with him because of his name Ernest. She once said: "my ideal has always been to love some one of the name of Ernest. There is something in that name that inspires absolute confidence. The moment Algernon first mentioned to me that he had a friend called Ernest, I knew I was destined to love you." (Wilde, 1985). His self-identification is actually based on others' recognition and acknowledge and so is Algernon's. Cecily told Algernon: "you must not laugh at me, darling, but it had always been agirlish dream of mine to love someone whose name was Ernest. There is something in that name thatseems to inspire absolute confidence. I pity any poor married woman whosehusband is not called Ernest." (Wilde, 1985). When Jack finally found his real name, Gwendolen said: "Ernest! My own Ernest! I felt from the first that you could have no other name!" (Wilde, 1985). With her confirmation, he reestablished his identity.

In addition, Miss Prism played an important part in establishing Jack's identity. Twenty-eight years ago, she put the manuscript of a three-volume fiction in the perambulator while she placed the baby in an old handbag by mistake and left it in the cloak-room of a railway station in London. What she did leads to Jack's identity crisis and the conflicts afterwards. However, it is her confession that enables Jack to regain his name and reestablish his identity.

What's more, Jack's father also functions as the other because his name is of 
much importance to Jack though he has been died and never appeared in the play. At the end of the play, Jack rushed to the bookcase to look through the Amy Lists, finding that his father's Christian name was Ernest, which confirms that he is naturally Ernest. The reason why he was eager to know his father's name is that only in this way can he know his own name and who he is, thus finishing his self-construction process. In Lacan's theory, a child can only transit from the Imaginary to the symbolic and form a socially acceptable identity with the recognition from the father (Zeng, 2017) [5]. Jack's father, as the other, is in the position of authority. Therefore, Jack has no choice but to identify with him. His desire to know his father's name is the desire to establish his real identity.

\section{Conclusions}

Lacan put forward the mode of "identification-disintegration-reidentfication" to elaborate on the self-identification process of individuals in Mirror Stage Theory. Jack and Algernon's self-construction process can be divided into the following three stages: the falsity of self-identification, the collapse of imaginary identity and the reestablishment of identity, which is in accord with Lacan's analysis.

In self-construction process, Jack and Algernon are lack of autonomy and controlling over themselves and their ego is established at the mercy of the other. To be exact, the other has become an integral part of the subject in the mirror stage because their ego is the crystallization of mirror images. In the stage of identification, they regard the imaginary mirror images as themselves, which foreshadows the collapse of their false identities. In the stage of disintegration, they function as the other to each other as well as themselves. The influence and controlling power of the other is more prominent in the stage of re-identfication. Without the other, their self-identification process would not be finished.

\section{Conflicts of Interest}

The authors declare no conflicts of interest regarding the publication of this paper.

\section{References}

[1] Reinert, O. (1956) Satiric Strategy in The Importance of Being Earnest. College English, 18, 14-18. https://doi.org/10.2307/372763

[2] Poague, L.A. (1973) The Importance of Being Earnest: The Texture of Wilde's Irony. Modern Drama, 16, 251-257. https://doi.org/10.1353/mdr.1973.0062

[3] Craft, C. (1990) Alias Bunbury: Desire and Termination in The Importance of Being Earnest. Representations, 31, 19-46.https://doi.org/10.2307/2928398

[4] Balkin, S. (2016) Realizing Personality in The Importance of Being Earnest. Modern Drama, 59, 26-48. https://doi.org/10.3138/md.0743

[5] Zeng, F.R. (2017) Western Literary Theories. Higher Education Press, Beijing.

[6] Wilde, O. (1985) The Importance of Being Earnest. Penguin Group Inc., New York. 